\title{
An Ergonomic survey of Health Status of the Handloom Weavers
}

\author{
Santu Durlov ${ }^{1}$, Atanu Saha ${ }^{2}$, Sasangbaha Mandi ${ }^{1}$, Subhashis Sahu ${ }^{1 *}$ \\ ${ }^{1}$ Ergonomics and Occupational Physiology Laboratory, Department of Physiology, University of Kalyani, Kalyani, India \\ ${ }^{2}$ Department of Physiology, Sister Nibedita General Degree College for Girls, Kolkata-700027, West Bengal, India \\ *Corresponding Author: Subhashis Sahu,Email: skcsahu@yahoo.co.in, Phone No. +919831316573(M)
}

Available online at: www.isroset.org

Received: 23/Jan/2019, Accepted: 08/Feb/2019, Online: 28/Feb/2019

\begin{abstract}
Weaving is a one of the time honored crafts in the globe. The handloom industry is mainly a rural based cottage industry, where the processes are done mainly manually. Some handloom product of West Bengal like "Sari" (a traditional Indian dress worn by females in India) appreciated worldwide. It is an extensive piece of art work exclusively done manually by the weavers. The product development encompasses a wide range of tasks such as manual sorting of raw materials, dyeing, cutting, starching and adjustment of loom, arrangement of thread and spindle insertion, etc. This study was aimed at evaluating the different health problems and socio-economic conditions of the handloom weavers. Three hundred forty (340) weavers were randomly taken from different districts of West Bengal and 108 people from the same localities and similar socioeconomic background were also taken as a referent. Detailed job profile of handloom weavers was also analyzed with the help of established standard questionnaire. It was observed that all types of weavers belong to low socio-economic condition and suffered from several health problems like pain in different body parts, eye constraint, respiratory problems and many more to say.
\end{abstract}

Keywords: Hand loom weavers, Ergonomics, Work related health problems, Unorganized sector.

\section{INTRODUCTION}

Weaving is a one of the oldest surviving traditional crafts in the world. It is a rural based cottage industry, where spinning, weaving and other processes are done mainly manually. A large number of people are engaged in handloom sector in West Bengal as well as in other parts of India. Some handloom product of West Bengal like "Sari" (a traditional Indian dress worn by females in India) appreciated worldwide. "Sari" is an extensive piece of art work exclusively done by hand weaving. The time taken to weave a sari depends on the degrees of art work. "Sari" with

Weaving job consist of multiple occupational risk factors like awkward posture, high force, repetitive movement, long duration of work and high visual demand. Unfortunately, the traditional handloom approach to occupational health studies has tended to concentrate mostly on organized sectors and has neglected the occupational health problems in the informal sector where the majority of populations of many developing countries live and works $[\mathbf{5 , 6 ]}$.

The handloom weaver's use manually operated looms that require the weaver to sit at the loom and operate foot pedals that hang below. The studies on handloom weavers of Tamil Nadu showed that pain in different body parts was the main complaint among the weavers; other complaints simple design or without design takes one day to complete whereas a sari with plenty or composite design may take 2-3 days to complete. The product development encompasses a wide range of tasks such as manual sorting of raw materials, dyeing, cutting, starching and adjustment of loom, arrangement of thread and spindle insertion, etc. [1,2].

Notwithstanding the present era of mechanization and computer aided design, the handloom sector depends exclusively on richness of diverse manual skills, representing the cultural and traditional art forms $[3,4]$.

included respiratory problems, eye problems, problems of digestive system, and sleep disturbances [7]. Study on the musculoskeletal disorders among the male handloom weavers showed that they suffered from pain in different body parts. The maximum discomfort felt in the lower back and knee, caused due to adopting awkward sitting postures for long time, repeated movements of the limbs, altogether puts the workers into stress $[8,9]$. Present survey was aimed at assessing health problems and socio-economic conditions of handloom weavers. In the following sections detailed methodology, findings and conclusive discussion has been enumerated. 


\section{METHODOLOGY}

\section{Subjects:}

Three hundred forty (340) handloom weavers from different district of West Bengal were randomly taken for this study. Among them one hundred ninety two (192) were traditional handloom weavers and one hundred forty eight (148) were jacquard loom weavers. One hundred eight (108) people from the same localities and similar socio-economic background were also taken as a referent group.

\section{Measurement of physical parameters:}

The basic physical parameters, such as height and the body weight of the weavers were measured by means of an anthropometric rod and a properly calibrated weighing machine respectively. From the anthropometric data the body mass index (BMI) were calculated and expressed in $\mathrm{kg} / \mathrm{m}^{2}[\mathbf{1 0}]$.

\section{Questionnaire study:}

An ergonomic questionnaire was developed; it consists of a series of questions with a number of preferred responses. The questions sought information about the socio-economic background, educational status, knowledge, attitude, health, work related aspects, etc.

Most of the weavers were both semi-literate and illiterate, so interviews were carried out verbally and responses were noted. The questions were prepared in English but were communicated to them in their local dialect (Bengali) during working hours or either before or after work hours. Socio-economic questionnaire were also administered for evaluation of their socio-economic status $[11,12]$.

\section{Statistical analysis:}

All statistical data have been analyzed by statistical software IBM SPSS version 21.0 in personal computer.

\section{RESULTS AND DISCUSSION}

\section{Types of handloom:}

It was observed that there were different types of handloom, work stations and product. Brief description is given below:

\section{A) Types of looms (based on their workstation) -}

i) Ground sitting handloom weavers: This is a traditional work station used by the handloom weavers. In this workstation the weaver sits on the floor or on a plank on the centre of a ditch with their leg hanging. They operate the pedals placed at the ditch to control the movement of loom.

ii) Bench sitting hand loom weavers: Some of the weavers use bench type work station in this work.

B) Other types, such as traditional handloom and jacquard loom.

\section{i) Traditional handloom weaver:}

Traditional handloom is very simple; the weavers sit on the ground and the legs were hanging down. The method of making these looms is very simple and the price is low. The traditional handloom weavers make a beautiful design of saries through their hands with needle.

\section{ii) Jacquard loom weaver:}

In 1801, Joseph Marie Jacquard created a mechanical device, which could make the handloom production process with complex patterns such as brocade, damask and matelasse. The loom is controlled by a "chain of cards", a number of punch cards, laced together into a continuous sequence. Multiple rows of holes are punched on each card, with one complete card corresponding to one row of the design whereas, a handloom was a simple machine used for weaving. In a wooden vertical-shaft loom, the heddles are fixed in place in the shaft. The warp threads pass alternately through a heddle, and through a space between the heddles (the shed), so that raising the shaft raises half the threads (those passing through the heddles), and lowering the shaft that lowers the same threads, the threads passing through the spaces between the heddles remain in place.

Most of the handloom weavers were from poor socio-economic background. They had to work in an illventilated room with poor illumination. In tropical region, during summer, the condition became worst due to increase in room temperature and humidity.

Self ratings of body part discomfort (BPD scale) study showed that the maximum discomfort was felt in the lower back followed by head, waist and fingers. In most of the work places $(96 \%)$ survey, illumination level was very poor even in day time. So, as weaving is fine visual task, inadequate illumination creates stress on eyes.

Table 1 shows that, the average age, height, weight and BMI (Body Mass Index) of the control subjects and handloom weavers. These physical characteristics were not significantly differs in control groups and handloom weavers. Control subjects were from same locality but engaged in other job except weaving. Both of the subjects i.e. control groups and handloom weavers belong to same socio-economic class.

Table 2 represented that, all the weavers were divided into two groups based on their types of loom they work with (Traditional handloom weavers and Jacquard loom weavers). The average age, weight and years of exposures between the both types of weavers were near about same but nutritional status i.e. body mass index (BMI) was comparatively low among the jacquard loom weavers than the traditional handloom weavers, but these parameters were not differed significantly.

\section{Economic background of the two types of handloom} weavers:

The handloom weavers were from poor economic background, so, they did not have sufficient scope for their education. The family profiles of the weavers were given in 
table 3. From the questionnaire study, it was seen that the handloom weavers in this study as depicted in the table 3 , about 50 percent of traditional handloom weavers were fully illiterate and jacquard loom weavers 16 percent (\%) were illiterate. Maximum of the jacquard loom weavers can only read $(62 \%)$ where less than $40 \%$ of the traditional weavers can only read. The percentages of jacquard loom weavers, who can both read and write, were more than the traditional handloom weavers.

\section{Health problems:}

It was observed that the weavers were exposed to different work stressors and hazardous environment. So, they had complaints about different occupational health problem. Complaints about different health problems are given in table 4.

Table 4 shows that the maximum health complaints (i.e. respiratory problems, cardiovascular problems, ENT, eye problems and pain in body parts) were significantly high among the handloom weavers than the control subjects.

An exploratory factor analysis (Table 5) was conducted for monitoring the reason of stress among the handloom weavers during working hours. Factor analysis indicated that common causes in all the stresses and also the main reason for each factor acting as the most important or dominant variables [13].

Three factors have been found in Table 5. Factor one is made up of skin diseases, cardiovascular problems and other health problems. The skin diseases and cardiovascular problems are the main components of factor one. Factor two is made up of ENT and digestive system. The ENT and digestive system are the key component of factor two. Factor three is made up of pain, respiratory problems and eye problems. Pain, respiratory problems and eye problems are main component of the factor three.

It was found from dendrogram in figure $\mathbf{1}$ that pain, eye problems and respiratory problems were belonging in same cluster. Digestive problems and ENT problems were belong to same cluster. Cardiovascular problems, skin diseases and others health problems were belong to same cluster.
From figure $\mathbf{1}$ it is clear that the pain and eye problems are the most common health problems in the huge number of weavers than the other health problems.

Figure 2 showed that the handloom weavers complained about different health problems such as respiratory problems, cardiovascular problems, digestive problems, ENT problems, eye problems, and pain on different body parts, skin disease and other health problems from the results of questionnaire study. Here it was seen that the traditional handloom weavers and jacquard loom weavers were suffering from pain in body part and it was more prevalent than other health problems. The percentage of pain was much higher in case of jacquard loom weavers than the traditional handloom weavers. In the same way different health problems i.e., respiratory problems, cardiovascular problems, digestive problems, skin disease etc., were also more prevalent among the jacquard loom weavers. However, the percentage of eye problems of the traditional handloom weavers was more than that of jacquard loom weavers. The goal of the science discipline of ergonomics is to find the best fit between worker and job environment. Handicraft is a tough occupation. Handicraft workers get backaches, hearing problem, breathing problem, joint pain and pain in lower abdomen more than any other health problem. The reasons, identified include unnatural work postures, use of hazardous chemicals, unsafe working practices, long working hours and high risks of accidents at work place, caused by unsafe conditions [14].

\section{CONCLUSION}

From the study, it can be concluded that all types of weavers belong to low socio-economic condition and that they were exposed to different work stressors and hazardous environment. Hence, they are suffering from different health problems like pain in body parts, eye problems and respiratory problems.

They not only sit for long hours continuously to weave but also bend forward to make a perfect art-work in each sari in low illuminations. The work environment was getting worse in summer time due to heat and ill ventilation. So, detail stressor wise study is needed

\section{Figures and Tables:}

Table 1: Physical characteristics between control group and handloom weavers.

\begin{tabular}{|c|c|c|c|c|}
\hline \multirow[t]{2}{*}{ Parameters } & \multicolumn{4}{|c|}{ Physical Characteristics between control group and handloom weavers. } \\
\hline & $\begin{array}{c}\text { Control Group } \\
(n=108)\end{array}$ & $\begin{array}{c}\text { Handloom weavers } \\
(n=340)\end{array}$ & t values & Results \\
\hline Age (years) & $\begin{array}{c}33.76 \pm 8.70 \\
(19-51)\end{array}$ & $\begin{array}{c}34.02 \pm 9.08 \\
(19-53)\end{array}$ & 0.2618 & NS \\
\hline Height $(\mathrm{cm})$ & $\begin{array}{c}161.65 \pm 5.73 \\
(152-173)\end{array}$ & $\begin{array}{c}162.45 \pm 5.84 \\
(145.2-173.0)\end{array}$ & 1.2458 & NS \\
\hline Weight (Kg) & $\begin{array}{l}60 \pm 8.91 \\
(45-75)\end{array}$ & $\begin{array}{c}59.58 \pm 9.4 \\
(40-68)\end{array}$ & 0.4095 & NS \\
\hline $\mathrm{BMI}\left(\mathrm{kg} / \mathrm{m}^{2}\right)$ & $\begin{array}{l}23.04 \pm 2.89 \\
(18.1-29.1)\end{array}$ & $\begin{array}{l}22.66 \pm 3.76 \\
(15.4-35.8)\end{array}$ & 0.9635 & NS \\
\hline
\end{tabular}


Mean $\pm \mathrm{SD}$ (range), $\mathrm{n}=$ number, NS= Non Significant

Table 2: Physical characteristics analysis between two types of handloom weavers (Traditional handloom weavers and Jacquard loom weavers).

\begin{tabular}{|l|c|c|c|c|}
\hline \multirow{2}{*}{ Parameters } & \multicolumn{3}{|c|}{ Physical characteristics are of two types of handloom weavers } \\
\cline { 2 - 5 } & $\begin{array}{c}\text { Traditional handloom weavers }(\boldsymbol{n}= \\
\text { 192) }\end{array}$ & $\begin{array}{c}\text { Jacquard loom weavers } \\
(\boldsymbol{n}=148)\end{array}$ & t values & Results \\
& $34.08 \pm 9.22$ & $33.91 \pm 8.94$ & & NS \\
& $(19-53)$ & $(19-52)$ & 0.1708 & \\
\hline Age (years) & $161.98 \pm 5.19$ & $163.15 \pm 6.12$ & 1.9055 & NS \\
& $(145.2-173.0)$ & $(149.0-173.0)$ & & NS \\
\hline Weight $(\mathrm{Kg})$ & $58.33 \pm 9.18$ & $57.61 \pm 9.25$ & 0.7146 & NS \\
& $(40-85)$ & $21.58 \pm 3.92$ & 1.8234 & NS \\
\hline BMI $\left(\mathrm{kg} / \mathrm{m}^{2}\right)$ & $22.32 \pm 3.54$ & $(15.8-29.7)$ & & \\
\hline Experiences (years) & $(15.4-34.9)$ & $16.96 \pm 8.53$ & 0.7640 & \\
& $16.27 \pm 8.04$ & $(4-34)$ & & \\
\hline
\end{tabular}

Mean \pm SD (range); $\mathrm{n}=$ number, NS= Non-Significant.

Table 3: Family features of the two types of handloom weavers.

\begin{tabular}{|c|c|c|c|c|c|}
\hline \multirow{2}{*}{$\begin{array}{c}\text { Demographic } \\
\text { parameters }\end{array}$} & \multicolumn{5}{|c|}{ Family features of the two types of handloom weavers } \\
\hline & Parameters & $\begin{array}{c}\text { Control Group, } \\
n=108(\%)\end{array}$ & $\begin{array}{c}\text { Total handloom weavers, } \\
n=340(\%)\end{array}$ & $\begin{array}{c}T H L W, \\
n=192(\%)\end{array}$ & $J L W, n=148(\%)$ \\
\hline \multirow{3}{*}{$\begin{array}{l}\text { Educational } \\
\text { Level }\end{array}$} & Illiterate & $39(36.11)$ & $118(34.71)$ & $94(48.96)$ & $24(16.22)$ \\
\hline & Can only read & $51(47.22)$ & $168(49.41)$ & $76(39.58)$ & $92(62.16)$ \\
\hline & Can both read and write & $18(16.67)$ & $54(15.88)$ & $22(11.46)$ & $32(21.62)$ \\
\hline \multirow[t]{3}{*}{ Marital status } & Married & $94(87.04)$ & $289(85.0)$ & $162(84.38 \%)$ & $127(85.81)$ \\
\hline & Unmarried & $14(12.96)$ & $33(9.71)$ & $21(10.94 \%)$ & $12(8.11)$ \\
\hline & Widow & 00.00 & $18(5.29)$ & $9(4.69 \%)$ & $9(6.08)$ \\
\hline \multirow[t]{4}{*}{ Children numbers } & No have children & $5(4.63)$ & $49(14.41)$ & $30(15.63 \%)$ & $19(12.84)$ \\
\hline & Children 1 & $39(36.11)$ & $114(33.53)$ & $50(26.04 \%)$ & $64(43.24)$ \\
\hline & Children's 2 & $46(42.59)$ & $138(40.59)$ & $85(44.27 \%)$ & $53(35.81)$ \\
\hline & Children's $>2$ & $18(16.67)$ & $39(11.47)$ & $27(14.06 \%)$ & $12(8.11)$ \\
\hline \multirow[t]{2}{*}{ Family type } & Nuclear & $89(82.41)$ & $272(80.0)$ & $154(80.21)$ & $118(79.73)$ \\
\hline & Joint & $19(17.59)$ & $68(20.0)$ & $38(19.79)$ & $30(20.27)$ \\
\hline \multirow{5}{*}{$\begin{array}{l}\text { Family } \\
\text { Members }\end{array}$} & Family member $=1-3$ & $16(14.82)$ & $38(11.18)$ & $11(5.73 \%)$ & $27(18.24)$ \\
\hline & Family members $=4$ & $27(25.0)$ & $74(21.77)$ & $25(13.02 \%)$ & $49(33.11)$ \\
\hline & Family members $=5$ & $24(22.22)$ & $79(23.24)$ & $40(20.83 \%)$ & $39(26.35)$ \\
\hline & Family members $=6$ & $33(30.56)$ & $95(27.94)$ & $65(33.85 \%)$ & $30(20.27)$ \\
\hline & Family members $=>6$ & $8(7.41)$ & $54(15.88)$ & $51(26.56 \%)$ & $3(2.03)$ \\
\hline \multirow[t]{3}{*}{ Experiences (years) } & $1-15$ & NA & $167(49.12)$ & $100(52.08)$ & $67(45.27)$ \\
\hline & $16-25$ & NA & $118(34.71)$ & $65(33.85)$ & $53(35.81)$ \\
\hline & $>25$ & NA & $55(16.18)$ & $27(14.06)$ & $28(18.92)$ \\
\hline
\end{tabular}

THLW=Traditional handloom weavers, JLW=Jacquard loom weavers, NA= Not Applicable, $\mathrm{n}=$ number, $(\%)=$ percentage of responses.

Table 4: Complaint about different health problems among control group and handloom weavers.

\begin{tabular}{|l|c|c|c|c|c|c|}
\hline \multirow{2}{*}{ Health problems } & \multicolumn{6}{|c|}{ Complaints about different health problems among control group and handloom weavers } \\
\cline { 2 - 6 } & \multicolumn{2}{|c|}{ Control Group (n=108) } & \multicolumn{2}{|c|}{ Handloom Weavers(n=340) } & p values & Results \\
\cline { 2 - 7 } & Yes & No & Yes & No & & \\
\hline $\begin{array}{l}\text { Respiratory } \\
\text { problems }\end{array}$ & $66(61.11)$ & $42(38.89)$ & $254(74.71)$ & $86(25.29)$ & 0.0052 & $\mathrm{~S}$ \\
\hline $\begin{array}{l}\text { Cardiovascular } \\
\text { problems }\end{array}$ & $56(51.85)$ & $52(48.15)$ & $227(66.77)$ & $113(33.23)$ & 0.0016 & $\mathrm{~S}$ \\
\hline Digestive problems & $68(62.96)$ & $40(37.04)$ & $248(72.94)$ & $92(27.06)$ & 0.0327 & $\mathrm{~S}$ \\
\hline
\end{tabular}




\begin{tabular}{|c|c|c|c|c|c|c|}
\hline ENT & $67(62.04)$ & 41(37.96) & $244(71.77)$ & $96(28.23)$ & 0.0378 & $S$ \\
\hline Eye problems & $62(57.41)$ & $46(42.59)$ & $266(78.24)$ & $74(21.76)$ & 0.0001 & $\mathrm{~S}$ \\
\hline Pain & $71(65.74)$ & $37(34.26)$ & $293(86.18)$ & $47(13.82)$ & 0.0001 & $\mathrm{~S}$ \\
\hline Skin diseases & $57(52.78)$ & $51(47.22)$ & $208(61.18)$ & $132(38.82)$ & 0.0761 & $\mathrm{NS}$ \\
\hline $\begin{array}{l}\text { Other } \\
\text { problems }\end{array}$ & $51(47.22)$ & $57(52.78)$ & $199(58.53)$ & $141(41.47)$ & 0.0258 & $\mathrm{~S}$ \\
\hline
\end{tabular}

Mean $\pm \mathrm{SD}$, range, $\mathrm{n}=$ number, $\mathrm{NS}=$ Non Significant, $\mathrm{S}=$ Significant

Table 5: Factorial analysis (Rotated Component Matrix) of variables (Health problems among the handloom weavers).
\begin{tabular}{|l|c|c|c|}
\hline ariable & \multicolumn{3}{|c|}{ Component } \\
\cline { 2 - 4 } & & $\mathbf{1}$ & \\
\hline Other health problems & 0.512 & \\
\hline Skin diseases & 0.768 & & \\
\hline ENT & & 0.537 & \\
\hline Cardiovascular problems & 0.624 & & \\
\hline Digestive system & & & \\
\hline Respiratory problems & & & 0.461 \\
\hline Pain & & & 0.443 \\
\hline Eye problems & & & 0.227 \\
\hline
\end{tabular}

Rescaled Distance cluster combine

$\begin{array}{lllcccc}\text { CASE } & 0 & 5 & 10 & 15 & 20 & 25 \\ \text { Label Num } & +-\ldots \ldots \ldots\end{array}$

Pain

Eye Problems

Resp. Prob.

Diges.Prob.

ENT

Card.prob.

Other Heal.Pr

Skin Dise.

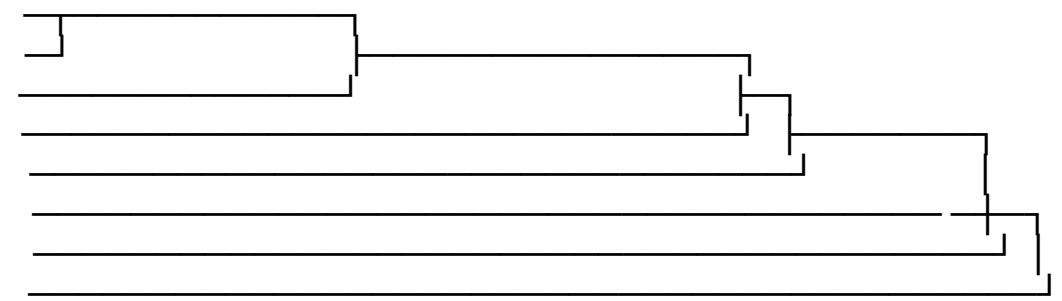

Figure 1: Dendrogram of (Health problems among the handloom weavers) variables. Single linkage (nearest neighborhood technique).

\section{Abbreviated Name: $\quad$ Extended Name}

Pain : Pain

Eye Problems : $\quad$ Eye Problems

Resp. Prob. : : Respiratory Problems

Diges. Prob. : $\quad$ Digestive Problems

ENT : $\quad$ ENT problems

Card.prob. : $\quad$ Cardiovascular problems

Skin Dise. $\quad$ : $\quad$ Skin Disease

Other Heal.Pr ～: Other Health Problems 


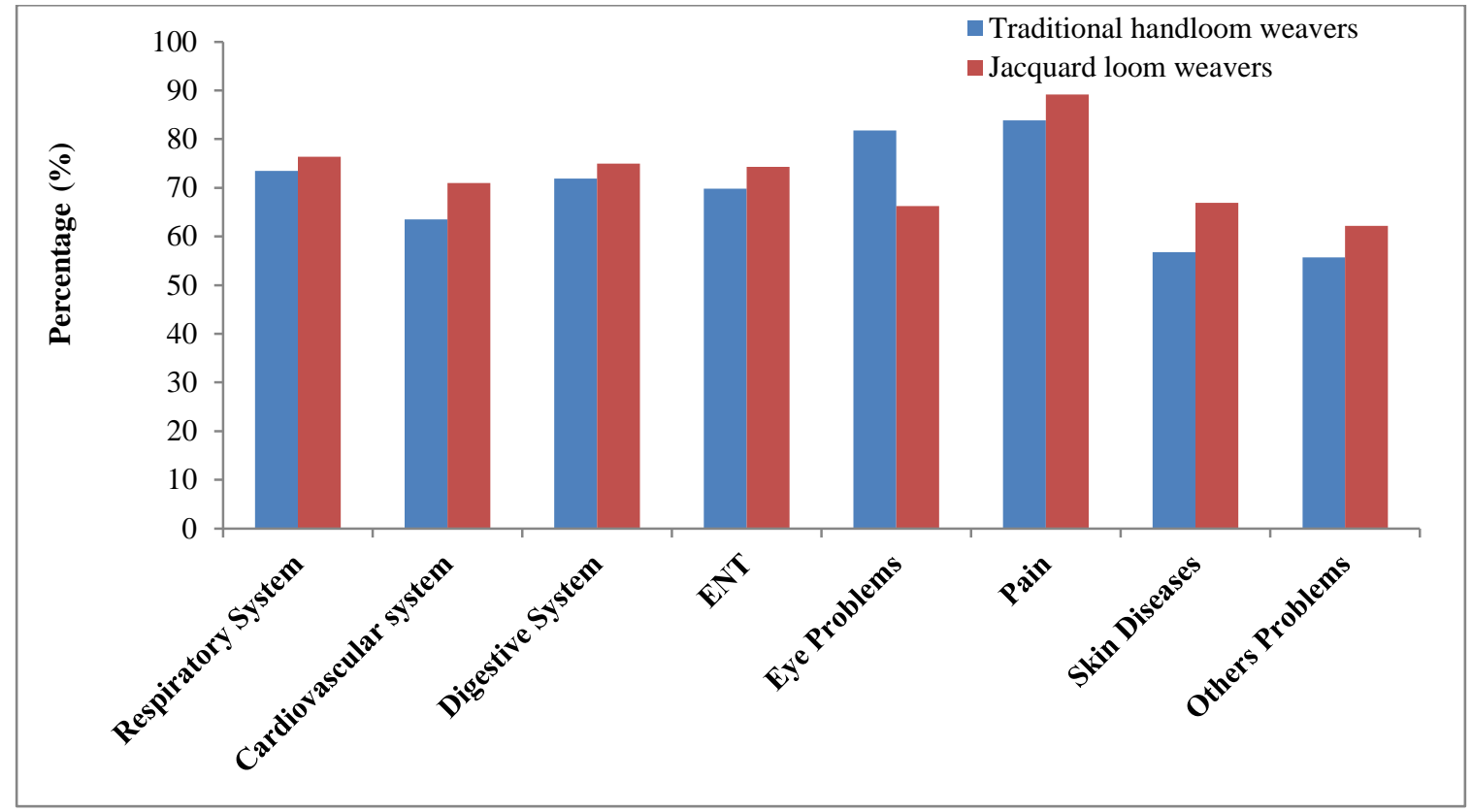

Figure 2: Different health problems among two types of handloom weavers.

\section{ACKNOWLEDGEMENT}

Authors are also grateful to the handloom weavers for their contribution and cooperation to conduct the study.

\section{REFERENCES}

[1]. A.Nag, H. Vyas, P.K. Nag, "Gender differences, work stressors and musculoskeletal disorders in weaving industries", Industrial Health, Vol. 48, pp.339- 348, 2010.

[2]. S. Sahu, S. Durlov, "Handloom weavers in India: An occupational physiological perspective", Asian-Pacific Newsletter on Occupational Health and Safety, Vol. 22, Issue. 3, pp. 60-62, 2015.

[3]. S. Pandit, P. Kumar, D. Chakrabarti, "Ergonomic problems prevalent in handloom units of North East India", International Journal of Scientific and Research Publications, Vol. 3, Issue. 1, pp.1-7, 2013.

[4]. S. Durlov, M. Sett, S. Sahu, "Comparative study of work related musculoskeletal problems between traditional hand loom and Jacquard loom weavers" , Journal of Environmental Physiology, Vol. 7, pp.20 -28, 2015.

[5]. D.C. Christiani, R. Durvasula, J. Myers, "Occupational health in developing countries: review of research needs", American Journal of Industrial Medicine,Vol.17, Issue 3, pp.393 - 401,1990.

[6]. S. Durlov, S. Sahu, "Cardiac stress among two types of handloom weavers, (Chapter: 19) In: Ergonomics in Caring for people (Editors, Roy G.G., Iqbal, R, Ganguli,AK and Khanzode, V), Springer Nature, Singapore, pp. 145-152, 2017.

[7]. R. Usharani, U.K. Lakshmi, "Socio economic and nutritional status of handloom weavers from
Thiruvannamalai District, Tamil Nadu", International Journal of Current Research, Vol. 6, Issue. 05, pp. 65136520, 2014.

[8]. S. Sahu, M. Sett, S. Durlov, "An ergonomic study on the musculoskeletal disorders among the male handloom weavers of West Bengal, India", Indian journal of physiology and allied sciences, Vol. 66, Issue 1, pp.16-27, 2012.

[9]. S. Durlov, M. Sett, S. Sahu, “A study on the development of work stress among two different groups of handloom weavers of West Bengal", Indian Journal of Physiology and Allied Sciences, Vol. 68, Issue 1, pp.10-17, 2014.

[10]. R. C. Weisell, "Body mass index as an indicator of obesity", Asia Pacific Journal of Clinical Nutrition, Vol. 11, Suppl. 8 (s8), pp. S681-S684, 2002.

[11]. B.Kuppuswamy, "Manual of socioeconomic status (Urban)", 1st ed. Delhi. Manasayan, pp. 66-72. 1981.

[12].Z. Shaikh, R. Pathak, "Revised Kuppuswamy and BG Prasad socio-economic scales for 2016", International Journal Community Medicine and Public Health, Vol. 4, No. 4, pp.997-999, 2017.

[13]. S. Mukherjee, C.K. Pradhan, I. Chakraborty, A. Saha, S. Thakur, S. Sahu, "General health status and morbidity pattern of bus drivers in West Bengal", International Journal of Scientific Research in Biological Science (ISSN 23477520), Vol. 5, Issue. 4, pp.29-39, 2018. 
[14]. S. Purnawati, "Occupational health and safety ergonomics improvement as a corporate responsibility of a Bali Handicraft Company: A case study", Journal of Human Ergology, Vol. 36, Issue. 2, pp.75-80, 2008.

\section{AUTHORS PROFILE}

Dr. S Durlov graduated in Physiology from Krishnanagar Government College, Nadia. He has M.Sc. degree in Physiology with specialization in Environmental Physiology and $\mathrm{PhD}$ degree in Physiology with specialization in Ergonomics and Occupational Physiology from Kalyani University, Nadia, West Bengal. He is presently working as a Research Associate in

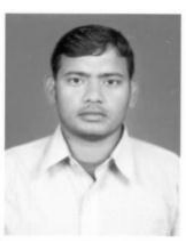
National Institute of Miners Health (NIMH) at Nagpur, Maharashtra. $\mathrm{He}$ has more than six years research experiences. He has published seven full papers in reputed national and international journals and he has oral presentation in different national and international seminars

Dr. A. Saha is presently working as an Assistant Professor of Physiology at Sister Nibedita Govt. College, Alipore, West Bengal. He completed his $\mathrm{Ph} . \mathrm{D}$ work in Physiology in 2014 from University of Kalyani. He has more than fourteen years of teaching experience in higher education and higher secondary level. He was a former head,

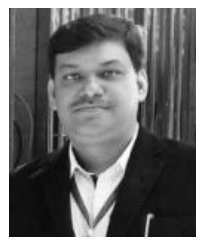
Dept of Physiology, Kaliganj Govt. College. He was the best paper award winner in Science Congress in 2012. He has published more than twelve papers in reputed national and international journal. Dr. Saha acted as an Editor of Police Journal (2004-2005), Police Training College, Govt. of West Bengal. Now he is a member of different academic and administrative bodies.

S.Mandi obtained M.Sc in Physiology from University of Kalyani in 2017. She is a Ph.D student of Physiology, University of Kalyani. Her main research work focuses on Ergonomics, Work Physiology, Occupational Health and intervention policy.

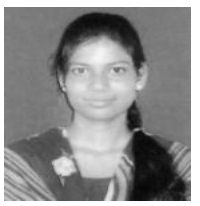

Dr. S. Sahu graduated from Presidency College, Calcutta. He has MSc. and $\mathrm{PhD}$ degree in Physiology with specialization in Ergonomics and Occupational Physiology from University of Calcutta. $\mathrm{He}$ is an Associate Professor a nd presently Head, Department of Physiology, University of Kalyani, West Bengal, India. He

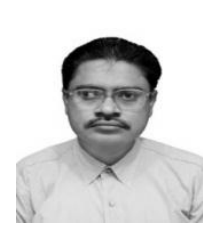
participated in several multinational collaborative studies on morningness orientation, mood disorders, eating habit and occupational heat exposure. His research work include evaluation of different occupational health problems including musculoskeletal disorders in different group of workers, its ergonomic evaluation, preventive measure, designing and sustainable remediation. He was conferred FABMS title from Association of Biomedical Scientist for his contribution in biomedical Sciences. His expertise includes analysis of posture in different conditions, design of work station and ergonomic evaluation of cognitive and motor skill. He has special interest in ergonomic evaluation capability and limitation of disabled person. He has published 94 full papers and seven $\mathrm{PhD}$ degrees have been awarded under his supervision. 